\title{
Using movement, diet, and genetic analyses to understand Arctic charr responses to ecosystem change
}

\author{
D. Cote $^{1, *}$, J. B. Dempson ${ }^{1}$, M. Piersiak ${ }^{1}$, K. Layton $^{2}$, S. Roul ${ }^{1}$, R. Laing ${ }^{3}$, J. Angnatok ${ }^{4}$, \\ I. Bradbury ${ }^{1}$
}

\author{
${ }^{1}$ Northwest Atlantic Fisheries Centre, Fisheries and Oceans Canada, St. John's, NL A1C 5X1, Canada \\ ${ }^{2}$ School of Biological Sciences, University of Aberdeen, Aberdeen AB24 2TZ, UK \\ ${ }^{3}$ Nunatsiavut Government, Nain, NL A0P 1L0, Canada \\ ${ }^{4}$ Putjotik Fisheries, Nain, NL A0P 1L0, Canada
}

\begin{abstract}
Arctic charr Salvelinus alpinus are a commercially and culturally valued species for northern Indigenous peoples. Climate shifts could have important implications for charr and those that rely on them, but studies that evaluate responses to ecosystem change and the spatial scales at which they occur are rare. We compare marine-phase habitat use, long-term diet patterns, and trends in effective population size of Arctic charr from 2 areas (Nain and Saglek) of Nunatsiavut, Labrador, Canada. Tagged charr in both areas frequently occupied estuaries but some also used other habitats that extended to the headland environments outside of their natal fjords. Despite the relatively small distances separating these study areas $(<200 \mathrm{~km})$, we observed differences in habitat use and diet. Northern stocks (including Saglek) were more reliant on invertebrates than southern stocks (e.g. Nain), for which capelin and sand lance were important prey. The use of coastal headlands also varied, with Saglek charr occupying these environments more frequently than those from Nain, which only used these habitats in 1 year of the study. Long-term commercial catches also indicate that the tendency for Nain charr to stay within fjords varies annually and relates to capelin availability. Despite the demonstrated capacity to alter diet and habitat use to changing environmental conditions, notable declines in effective population size were associated with the regime shift of the 1990s in the northwest Atlantic. Collectively, these results demonstrate that behavioral plasticity of Arctic charr may be insufficient to deal with the large environmental perturbations expected to arise from a changing climate.
\end{abstract}

KEY WORDS: Diet $\cdot$ Telemetry $\cdot$ Effective population size $\cdot$ Long-term monitoring $\cdot$ Labrador · Nunatsiavut

\section{INTRODUCTION}

Arctic charr Salvelinus alpinus are an iconic Arctic species native to a wide latitudinal gradient (Johnson 1980) that extends from the Arctic to north temperate regions (Reist et al. 2013). Across this range, this species exhibits a variety of adaptations (Dallaire et al. 2021) including remarkable phenotypic diversity within both freshwater resident and anadromous life histories (Klemetsen et al. 2003). In all but the south-

*Corresponding author: dave.j.cote@gmail.com ern extents of their range, anadromy is a common life history trait (Klemetsen et al. 2003) that allows charr to quickly increase somatic reserves in productive coastal environments before returning to freshwater to reproduce and overwinter (Klemetsen et al. 2003).

Behavioral plasticity is also common within anadromous populations of charr. At sea, for example, charr occupy habitats that range from sheltered estuaries to coastal headlands, show variation in marine residency times (Dempson \& Kristofferson 1987, Gulseth

(C) The authors and Fisheries and Oceans Canada 2021. Open Access under Creative Commons by Attribution Licence. Use, distribution and reproduction are unrestricted. Authors and original publication must be credited.

Publisher: Inter-Research · www.int-res.com 
\& Nilssen 2000, Klemetsen et al. 2003, Spares et al. 2015, Moore et al. 2016, Harris et al. 2020), occupy a variety of thermal habitats (Rikardsen et al. 2007a, Spares et al. 2012, Harris et al. 2020, Mulder et al. 2020), and consume diverse prey often dominated by pelagic fish and plankton (e.g. amphipods), but also items such as insects and benthic organisms (Dempson et al. 2002, Klemetsen et al. 2003, Rikardsen et al. 2007b, Spares et al. 2012, Davidsen et al. 2020). Despite this plasticity, marine habitat use within populations can remain stable across years, even during changing environmental conditions (Harris et al. 2020).

While researchers have documented phenotypic variation over wide geographic scales, less is known about how behavioral variation and plasticity are manifested over extended temporal and smaller spatial scales (but see Dempson \& Kristofferson 1987, Dempson et al. 2002, Davidsen et al. 2020), particularly across latitudinal gradients over which climate responses are likely to occur in the near future. Such information is important to detect and interpret the responses of Arctic charr to the rapidly changing Arctic (Reist et al. 2006, Power et al. 2012, Dallaire et al. 2021, Layton et al. 2021).

The challenges to understanding variability and plasticity in Arctic charr behavior are two-fold: (1) there is a scarcity of data sets of appropriate spatial and temporal scales and (2) there is a lack of data associating behavior with biotic environmental variables such as prey availability. Though considerable research is available on the marine movements of Arctic charr (e.g. Bégout Anras et al. 1999, Spares et al. 2015, Moore et al. 2016, Harris et al. 2020), it is difficult to sustain these projects over extended temporal periods across a latitudinal gradient while concurrently monitoring biotic/abiotic variables of interest. One area where extensive behavioral data exist is in Nunatsiavut, northern Labrador, Canada, where conventional mark-recapture tagging studies have been conducted over several decades and supported by diet and morphometric studies (Dempson \& Kristofferson 1987, Power et al. 2000, Dempson et al. 2002, 2008). These studies provide a baseline that, when coupled with contemporary telemetry and genomic methods, can be used to explore spatial and temporal variation in Arctic charr marine movement behavior and links to marine-phase diets.

Evaluating threats to southern sub-Arctic anadromous populations from further climate shifts and predicting changes to more northerly populations will depend on understanding the adaptability of local populations and their capacity to deal with ecosystem shifts. Past environmental disruptions can inform our understanding of the capacity of fauna to accommodate ecological change. For example, a regime shift coinciding with unusually cold ocean temperatures and lower productivity occurred in the northwest Atlantic in the 1990s (Pedersen et al. 2017). This time period was also associated with changes in species distributions and abundance (Colbourne 2004, Rose 2005a, Carscadden et al. 2013), as well as the decline of many important commercial fishery populations (Bundy et al. 2009, Mills et al. 2013, Pedersen et al. 2017). During this period the abundance of capelin Mallotus villosus declined in coastal areas of Newfoundland and Labrador (Buren et al. 2019), affecting the diets of a variety of fish, bird, and marine mammal species (Taggart et al. 1994, Lawson \& Stenson 1995, Montevecchi \& Myers 1997, Bryant et al. 1999, Rowe et al. 2000, Dempson et al. 2002) including Arctic charr (Dempson et al. 2002). As climate change progresses, other broad redistributions of species (Perry et al. 2005, Rose 2005b) and productivity are expected (Moore et al. 2018), which could have important repercussions on species like Arctic charr.

In this study, we (1) apply acoustic telemetry data to evaluate spatial differences in marine habitat use by Arctic charr from 2 regions of northern Labrador (Saglek Fjord and Nain Bay); (2) evaluate if observed patterns in habitat use are stable over time as inferred by historical diet and catch data from Nain Bay; and (3) use existing hindcasted indices of effective population size to assess whether populationspecific responses in diet and habitat use were sufficient to safeguard Nain Bay populations during times of strong environmental change.

\section{MATERIALS AND METHODS}

\subsection{Study area}

Our study was conducted in the coastal waters of the Nunatsiavut region of Labrador, Canada, a land claim area established for the Labrador Inuit. The orientation of the northern Labrador coastline lends itself well to studying potential climate change responses, since conditions in southern areas may foreshadow expected changes further north and therefore help to predict future effects of climate change (Layton et al. 2021). The coastal waters of this area extend $20 \mathrm{~km}$ offshore and encompass $48690 \mathrm{~km}^{2}$. Labrador Inuit are a critical part of this ecosystem, relying on species such as Arctic charr for subsistence and economic opportunities. 


\subsection{Acoustic telemetry}

Movements of Arctic charr were followed in 2 coastal regions of Nunatsiavut separated by approximately $200 \mathrm{~km}$ (Fig. 1). Saglek Fjord is $65 \mathrm{~km}$ in length, $14 \mathrm{~km}$ at its widest point, and is bathymetrically characterized by 7 underwater basins (80 to $256 \mathrm{~m}$ ) separated by sills (Brown et al. 2012, Simo-Matchim et al. 2017). The second region, hereafter referred to as Nain, is occupied by charr of the Nain stock complex (Dempson et al. 2002; our Fig. 1), and is more geographically complex due to the presence of islands that extend outside of Anaktalak Bay, Nain Bay, Tikkoatokak Bay, and Webb Bay. The Nain region is approximately $50 \mathrm{~km}$ wide with maximum depths reaching at least $110 \mathrm{~m}$ (Nutt 1953), though its bathymetry remains largely unmapped. Sea ice is common to both regions, occurring typically from November to mid-June or early July (McCarney et al. in press).
We used an array of Vemco acoustic receivers (VR2W and VR2ARs, Innovasea) to monitor the marine movements of Arctic charr from the summer of 2018 to autumn of 2019. Receivers were positioned to monitor habitat use and the timing of migration events to and from the marine environment of tagged animals through the course of their marine residency period. Consequently, we placed receivers in river estuaries, gateways within, and at the seaward extent of fjords to track exits to the coastal headlands. The more complex nature and variety of migratory pathways off Nain required more receivers for coverage. In total, we deployed 43 receivers between our 2 study sites: 25 were deployed off Nain and 18 in Saglek Fjord (Fig. 1). Of the 43 receivers deployed, 23 (15 in Nain and 8 in Saglek) were VR2-ARs that were recovered with acoustic releases. The remaining receivers were VR2Ws and recovered with ground lines.

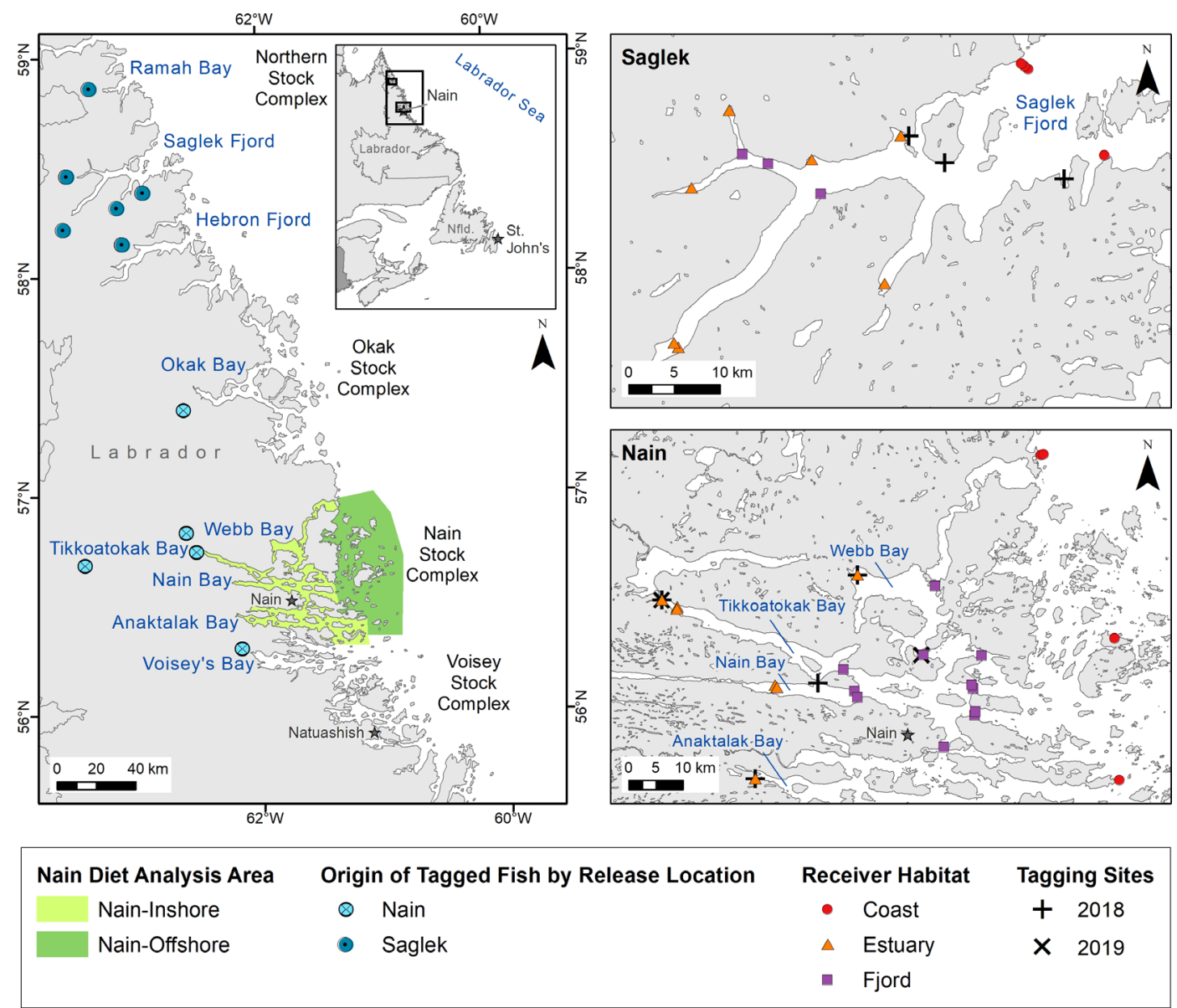

Fig. 1. Stock complexes of Arctic charr in northern Labrador, Canada as defined by Dempson \& Kristofferson (1987). Ramah Bay, Saglek Fjord, and Hebron Fjord comprise the areas of the northern stock. River origin of fish tagged in marine environments of Nain and Saglek are shown at the point where rivers empty/drain into the ocean. One fish tagged in Nain originated from the Okak stock complex. Right panels indicate receiver locations and tagging areas within the 2 study systems (Saglek Fjord and Nain). Different habitat types are denoted by receiver color and shape 
We tagged charr in 2018 in Saglek Fjord (July 2526, 2018) at Torr Bay, Branagin Island, and Jens Haven Island, and in Nain (August 2-4, 2018) at Webb Bay, Tikkoatokak Bay, Nain Bay, and Anaktalak Bay (Fig. 1, see Table S1 in the Supplement at www.int-res.com/articles/suppl/m673p135_supp.pdf). We also tagged charr in Nain in Webb Bay (July 31) and Tikkoatokak Bay (August 1) in 2019. Fish were collected using either barbless, single hook fishing lines or $4 \frac{1}{2}$ inch $(11.5 \mathrm{~cm})$ gillnets. Tagged fish in Saglek ranged from 45.7 to $64.0 \mathrm{~cm}$ (mean $53.7 \mathrm{~cm}$ ), whereas those from Nain ranged from 41.5 to $63.5 \mathrm{~cm}$ (mean $50.4 \mathrm{~cm}$ ) (Table S1). Based on fish length, we estimated ages to range from to 7 to $14 \mathrm{yr}$ (Dempson et al. 2008). Once captured, we measured length, and took a small clip of tissue $\left(\sim 1 \mathrm{~cm}^{2}\right)$ from the caudal fin to genetically assign a subset of fish to their natal river (see Section 2.3). Prior to release, tagged charr were allowed to recover in a plastic tub equipped with air pumps and flowing sea water. In total, 95 fish (40 in Saglek, 44 in Nain in 2018, and 11 in Nain in 2019) had uniquely coded Vemco V13 (36 [length] $\times$ $13 \mathrm{~mm}$ [diam.], $9.2 \mathrm{~g}$ in air, tag life: $602 \mathrm{~d}$ ) or V13T (46 $\times 13 \mathrm{~mm}, 9.7 \mathrm{~g}$ in water, tag life: $498 \mathrm{~d}$ ) transmitters surgically implanted in their abdominal cavities. Transmitters emitted pulses at random intervals between 60 and $120 \mathrm{~s}$ to minimize signal collisions that might occur if multiple tags were in close proximity.

We filtered our data of suspected mortality or tagshedding events (i.e. removing individuals that consistently remained in the vicinity of a receiver beyond normal migration periods), grouping the remaining data into individual detection events at specific receivers using the R package GLATOS (https://gitlab. oceantrack.org/GreatLakes/glatos). Occupancy was measured in 3 different habitat types using detections on receivers located in estuarine (immediate proximity of a freshwater input), fjord, and coastal (headlands outside of fjords) habitats (Fig. 1).

\subsection{Genetic assignment to river of origin}

Populations of Arctic charr on the Labrador Coast mix in the marine environment (Dempson \& Kristofferson 1987, Layton et al. 2020). We used tissue samples from 72 of the 84 fish tagged in 2018 (40 in Saglek and 32 in Nain; Table S1) to extract DNA and genotype 111 genome-wide microsatellite loci following Layton et al. (2020). Individual fish were assigned to river or region of origin (reporting group) using a Bayesian mixed stock fishery analysis in the R package rubias (Anderson 2017, Moran \& Ander- son 2019), as described by Layton et al. (2020). Only assignments with a probability of $>0.80$ were reported. Previous work suggests assignment accuracy using these loci and baseline is approximately $90 \%$.

\subsection{Diet analysis}

We examined temporal and spatial variation in charr diet using long-term monitoring data collected from 5680 individuals harvested in the northern Labrador charr fishery (1982-2008). This dataset was a temporally extended version of that explored by Dempson (1995) and Dempson et al. (2002) and was reanalyzed within a multivariate framework to focus on prey community differences among stock complexes and fishing areas (Fig. 1). Samples were collected in all 27 years from inshore areas of Nain (1982-2008) but only subsets of years were collected for other stocks, which ranged from 6 (Okak) to 22 (offshore Nain) years of data (Table S2).

Prey from charr stomachs were identified according to fish and invertebrate taxa and categorized by abundance and biomass metrics as described in Dempson et al. (2002). Additionally, for the years 19882008, quartiles of stomach fullness (i.e. $0=$ empty and 4 = full) were recorded for each fish and converted to percent fullness. To reduce autocorrelation of samples, we averaged stomach content biomass by sampling day and charr fishing area (Fig. 1). We used the Bray-Curtis Index (Bray \& Curtis 1957) to analyze community similarity and dissimilarity in biomass. We identified prey taxa that typified (i.e. contributed most to within-group similarity values) stocks and months, and discriminated (i.e. contributed most to dissimilarity values) among groups using SIMPER (PRIMER 7). Differences in prey communities across stocks, years, and months were evaluated through PERMANOVA (PERMANOVA+1.0.3; 9999 permutations), a permutation-based multivariate analog of ANOVA (Anderson 2001). Since the full model had a significant interaction between year and month, we analyzed 3 more simple models: (1) a model applied to the entire diet dataset with fixed terms for stock and month, and a stock $\times$ month interaction; (2) for Saglek data, a model with fixed terms for year, month, and a year $\times$ month interaction term; and (3) for Nain, a model that included the capture area (Inshore/Offshore) along with month, year, and all interaction terms. We presented these data using multi-dimensional scaling (MDS) of centroids. Centroids (representations of multivariate central tendency) were derived from Principal Coordinates Analysis (PCO) 
(Gower 1966) and used to simplify visual representations of biomass data. We also evaluated the consistency of interannual seriation in diets from charr caught in inshore and offshore areas of Nain by comparing stock-specific annual centroid similarity matrices using a permutation test of Spearman's rank correlation coefficients (RELATE algorithm in PRIMER version 7; 999 permutations).

We further examined temporal data of stomach fullness for Nain charr to evaluate whether food availability explained patterns in marine migration to offshore areas. Stomach fullness patterns across years for July and August for inshore and offshore stocks were visualized with Generalized Additive Models (shrinkage cubic regression spline, mgcv package v.1.8-31, Wood 2019) in R (v.3.6.3, R Core Team 2020). We also applied a linear model to evaluate if there was a negative relationship between stomach fullness of the inshore stock and the proportion of charr captured offshore in Nain's commercial fishery. Such a relationship would provide support for the hypothesis that Nain area charr are more likely to undertake more extensive marine migrations in years where food availability was low in inshore areas.

\subsection{Effective population size}

We evaluated responses of charr populations to shifts in diet using effective population size $\left(N_{\mathrm{e}}\right)$ data derived from Layton et al. (2021). Briefly, Layton et al. (2021) used LinkNe (Hollenbeck et al. 2016), a method that combines estimates of recombination rate with linkage disequilibrium, to estimate $N_{\mathrm{e}}$ from 1900-2013 with 968 single nucleotide polymorphisms (SNPs) from an 87k SNP array (Nugent et al. 2019) that had corresponding linkage map information (Nugent et al. 2017). LinkNe was run with bins of 0.05 Morgans and including only SNPs with minor allele frequency exceeding 0.05 . We binned estimates by generation, and approximate years were calculated assuming a generation time of 4 yr. Here, we extracted $N_{\mathrm{e}}$ data for 8 populations from the Nain region from 1990-2013.

\section{RESULTS}

\subsection{Genetic assignments of tagged fish}

Bayesian mixed stock fishery analysis assigned 72 tagged fish to a river but only 55 (75\%) surpassed the $80 \%$ assignment certainty threshold (Table S1). These analyses indicated that the fish tagged in Saglek Fjord originated from within Saglek (Southwest Arm River [n = 13], Kiyuktok Brook [ $=7$ ], Pangertok Brook [n $=1]$, Ugjuktok River [ $=2]$ ), or neighboring waterbodies within $50 \mathrm{~km}$ such as Hebron Fjord (Ikarut River [ $\mathrm{n}=11]$ ) and Ramah Bay (Stecker River [n = 2]) (Fig. 1). Fish tagged in the Nain stock complex originated from Nain Bay (Fraser River $[\mathrm{n}=1]$, Kamanatsuk Brook [ $n=7$ ], Kingurutik River [ $n=8]$ ), southern Anaktalak Bay (Ikadlavik Brook [n = 7]), and Webb Bay (Ikinet Brook [n = 1]) (Fig. 1). Tagged fish from Saglek (mean length $53.7 \mathrm{~cm}$ ) were significantly longer $(t=3.22, \mathrm{p}=0.002)$ than those from Nain (mean length $50.4 \mathrm{~cm}$ ).

\subsection{Movement}

We acquired telemetry data for 75 charr: 29 from Saglek and 46 from Nain (38 tagged in 2018 and 8 tagged in 2019). From our initial group of tagged fish, we were unable to detect 19 after tagging occurred, and assumed they left our array, had a malfunctioning transmitter or died beyond detection of our receivers. We excluded an additional individual due to suspected mortality or tag shedding (e.g. Lacroix et al. 2004). Data for this fish consisted of a continuous string of detections on 1 receiver extending from roughly the date of tagging through winter months and no detections on other receivers in the subsequent year. Among the remaining fish, 1 individual appeared to die or shed a tag after previous, distinct movements and therefore post-mortality data for this fish were also excluded. Three other individuals were detected only once (all in estuaries), which was insufficient to make a detection event within the GLATOS package and thus they were also excluded from further analysis.

We last detected the majority of tagged charr in both Saglek (23 of 29) and Nain (24 of 44) in 2018 in estuaries of the study area. It was assumed that the remainder overwintered in rivers outside the respective study areas. Moreover, we only detected a subset of the fish tagged in $2018(45 \%, \mathrm{n}=13$ in Saglek and $34 \%, \mathrm{n}=15$ in Nain) the following year. Migration timing into freshwater in $2018\left(t_{29}=1.55, \mathrm{p}=0.131\right)$ and to the ocean in $2019\left(t_{12}=-0.58, \mathrm{p}=0.58\right)$ did not differ across study locations. The mean date of migration into rivers was August 9 for Nain fish and August 16 for Saglek fish. Mean dates of migration back to the marine environment were June 6 and June 4 for Nain and Saglek respectively (Fig. 2A). We did not detect tagged individuals in more than 1 study region. 

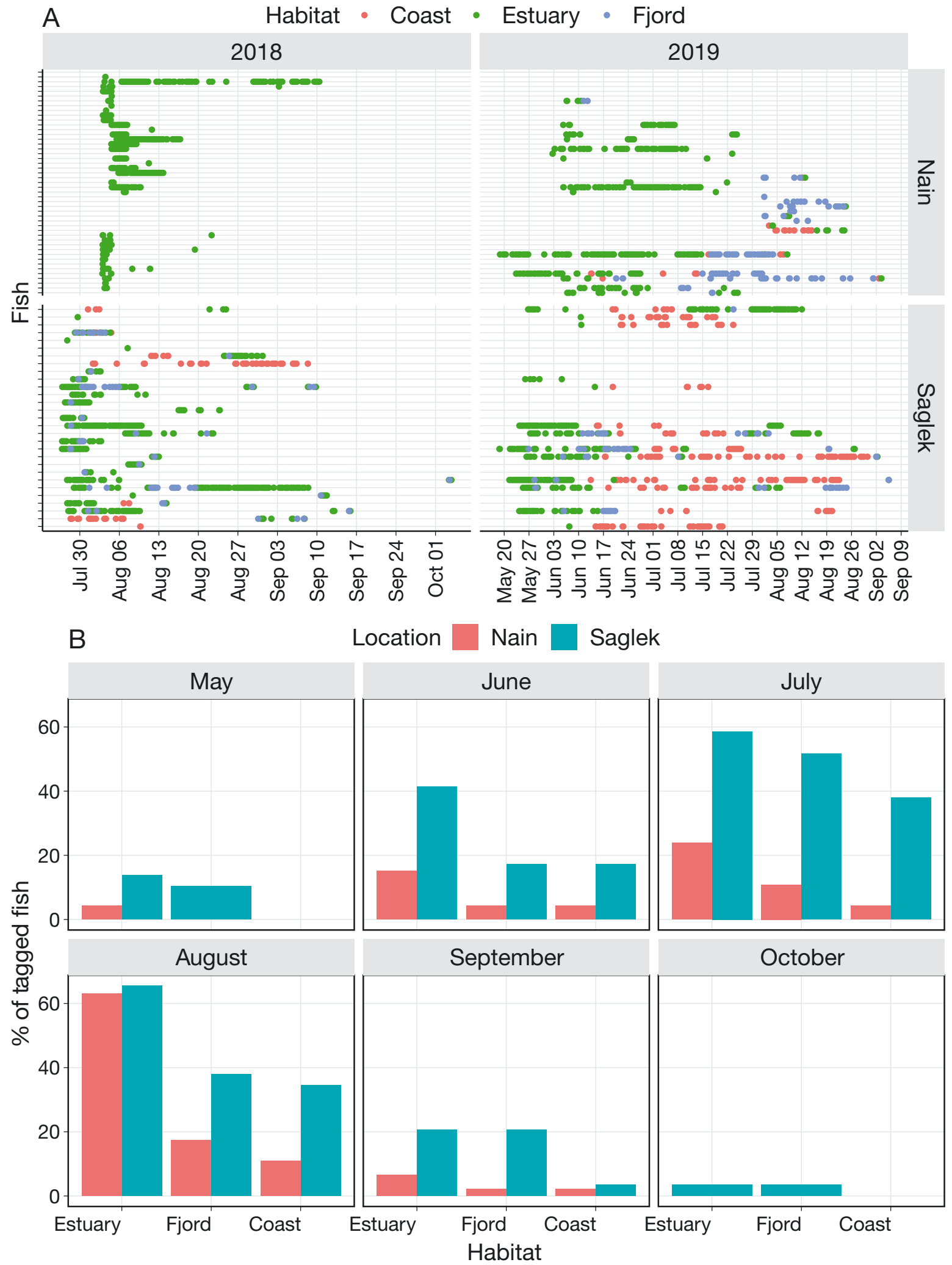

Fig. 2. (A) Detections (•) of Arctic charr in different habitats (estuary, fjord, and coast) across 2018 (left panel) and 2019 (right panel) in Nain and Saglek. Rows of detections represent multiple records of individual fish. (B) Number of Arctic charr detected by receivers in estuarine, fjord and coastal habitats by month during 2018 and 2019 in waters off Nain (n = 45) and 
Seventy-two individuals generated marine habitat occupancy information over the 2018 and 2019 monitoring period. We recorded 345 occupancy events for 27 fish in Saglek, and 232 events from 45 fish in Nain (37 tagged in 2018 and 8 tagged in 2019). Of these fish, we observed $93 \%$ occupying estuarine environments in both Saglek and Nain during the marine residency period but with a greater proportion of Saglek charr utilizing fjord or coastal environments (78 and $63 \%$, respectively) compared to Nain (27 and 16\%, respectively) (Fig. 2B). Moreover, in Nain the use of fjords and coastal habitats only occurred in 2019 even for fish detected in both study years (Fig. 2A). Tagged fish did not use coastal headland areas until June, and their occupancy only became relatively high in July and August for Saglek and peaked in August for Nain. We detected only a small percentage of individuals at coastal receivers in September and we detected no fish in these areas by October.

\subsection{Diet and changes to effective population size}

Charr diets along the north coast of Labrador revealed considerable variation at spatial scales within and among study regions ( $\mathrm{p}<0.001$; Fig. $3 \mathrm{~A}$ ), and at temporal scales of months to decades (Fig. 3B). At the largest spatial scales, the Northern stock was most unique with a diet that included a higher proportion of non-fish prey such as amphipods (Table 1). In contrast, diets of charr captured in Nain Inshore largely comprised fish such as capelin and sand lance Ammodytes spp. (Table 1). Charr in Nain Offshore maintained an intermediate level of piscivory relative to Nain Inshore and Northern charr (Fig. 3A, Table 1). Diets of charr from other areas (e.g. Okak and Voiseys) were more similar to Nain Inshore (Fig. 3A). With the exception of Cottid sculpins and Parathemisto amphipods (Nain Inshore only), biomass of all prey taxa was lower in charr from the Northern area.

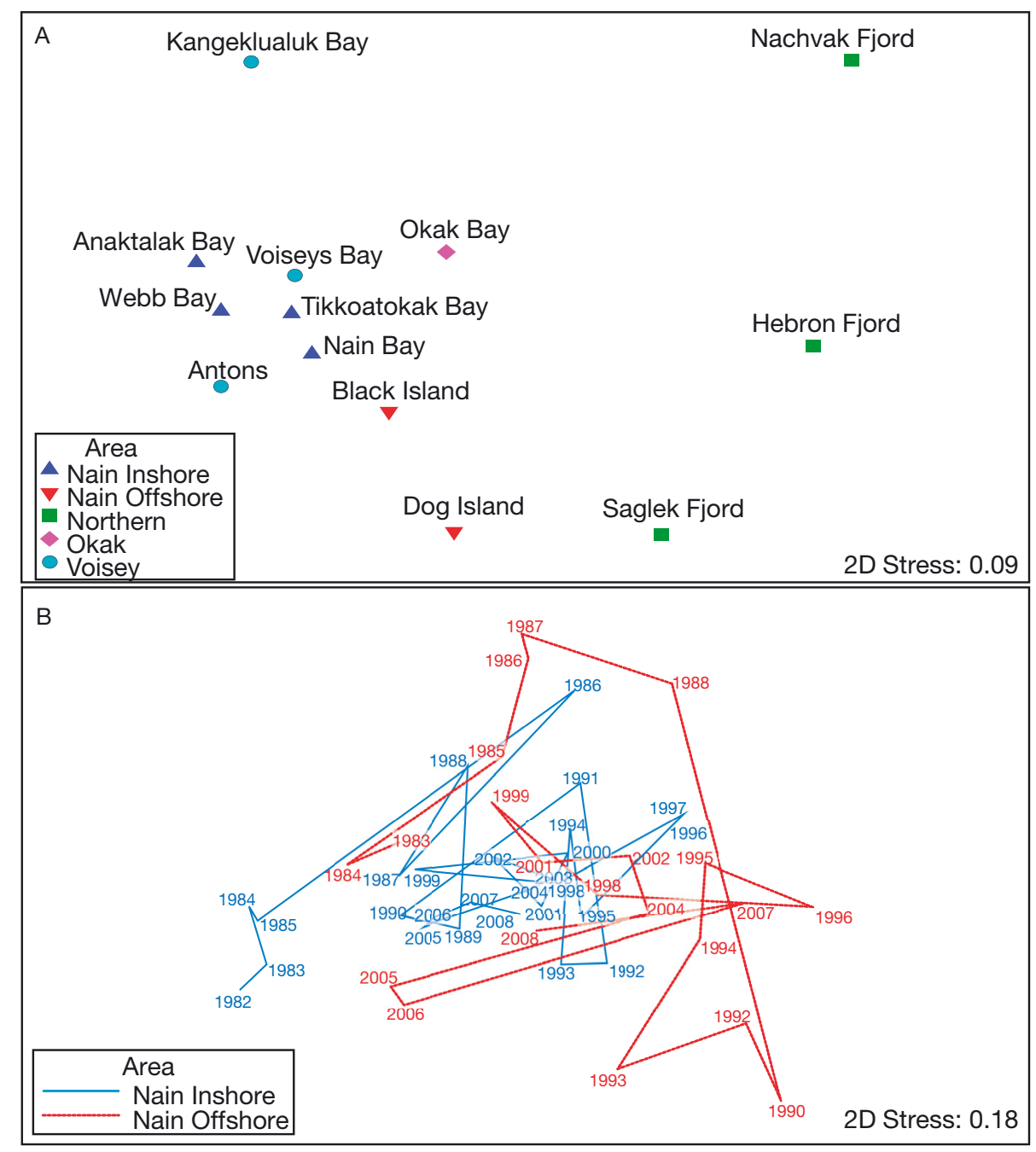

Fig. 3. (A) Spatial patterns of Arctic charr diets for fish captured at commercial fishing locations of the northern Labrador Coast (see Fig. 1 for locations). (B) Patterns of Arctic charr diets across years for charr caught in Nain Inshore and Nain Offshore. Lines indicate the time series progression for each area. Proximity of points in these non-metric multidimensional scaling plots reflect diet similarity (Bray-Curtis) of PCOderived centroids 
Table 1. Prey items differentiating diet among Arctic charr captured in northern stocks (including Saglek Fjord, see Fig. 1) and in inshore and offshore areas of Nain. Dissimilarity scores are derived using the Bray-Curtis Index

\begin{tabular}{|c|c|c|c|c|}
\hline $\begin{array}{l}\text { Nain Inshore vs. Nain Offshore } \\
\text { Taxa }\end{array}$ & $\begin{array}{l}\text { Nain Inshore average } \\
\text { diet biomass (g) }\end{array}$ & $\begin{array}{l}\text { Nain Offshore average } \\
\text { diet biomass }(\mathrm{g})\end{array}$ & $\begin{array}{c}\text { Dissimilarity } \\
\text { contribution }(\%)\end{array}$ & $\begin{array}{c}\text { Cumulative } \\
\text { dissimilarity (\%) }\end{array}$ \\
\hline Capelin & 11.9 & 5.9 & 21.4 & 21.4 \\
\hline Sculpins (Cottid) & 3.2 & 6.8 & 12.4 & 33.8 \\
\hline Sand lance & 5.0 & 4.8 & 10.9 & 44.8 \\
\hline Amphipod (Parathemisto spp.) & 1.7 & 4.8 & 9.1 & 53.9 \\
\hline Sculpin (Myoxocephalus) & 1.7 & 4.5 & 8.8 & 62.7 \\
\hline Amphipod (Hyperid) & 1.6 & 3.4 & 7.4 & 70.1 \\
\hline $\begin{array}{l}\text { Nain Inshore vs. Northern } \\
\text { Taxa }\end{array}$ & $\begin{array}{l}\text { Nain Inshore average } \\
\text { diet biomass }(\mathrm{g})\end{array}$ & $\begin{array}{l}\text { Northern average } \\
\text { diet biomass }(\mathrm{g})\end{array}$ & $\begin{array}{c}\text { Dissimilarity } \\
\text { contribution (\%) }\end{array}$ & $\begin{array}{c}\text { Cumulative } \\
\text { dissimilarity (\%) }\end{array}$ \\
\hline Capelin & 11.9 & 2.5 & 21.7 & 21.7 \\
\hline Sculpins (Cottid) & 3.2 & 6.3 & 14.4 & 36.0 \\
\hline Amphipod (Parathemisto spp.) & 1.7 & 6.9 & 13.3 & 49.3 \\
\hline Sand lance & 5.0 & 0.8 & 11.8 & 61.1 \\
\hline Fish (unidentified) & 3.9 & 1.0 & 7.7 & 68.7 \\
\hline Sculpin (Mуохосерhalus) & 1.7 & 0.8 & 5.0 & 73.7 \\
\hline $\begin{array}{l}\text { Nain Offshore vs. Northern } \\
\text { Taxa }\end{array}$ & $\begin{array}{c}\text { Nain Offshore average } \\
\text { diet biomass }(\mathrm{g})\end{array}$ & $\begin{array}{l}\text { Northern average } \\
\text { diet biomass }(\mathrm{g})\end{array}$ & $\begin{array}{c}\text { Dissimilarity } \\
\text { contribution }(\%)\end{array}$ & $\begin{array}{c}\text { Cumulative } \\
\text { dissimilarity (\%) }\end{array}$ \\
\hline Sculpins (Cottid) & 6.8 & 6.3 & 16.0 & 16.0 \\
\hline Amphipod (Parathemisto spp.) & 4.6 & 6.9 & 14.9 & 30.9 \\
\hline Capelin & 5.9 & 2.5 & 11.9 & 42.8 \\
\hline Sand lance & 4.8 & 0.8 & 8.8 & 51.6 \\
\hline Sculpin (Myoxocephalus) & 4.5 & 0.8 & 8.6 & 60.2 \\
\hline Amphipod (Hyperid) & 3.4 & 1.1 & 7.0 & 67.1 \\
\hline Pteropods & 2.0 & 0.3 & 4.8 & 71.9 \\
\hline
\end{tabular}

The degree of variability explained by temporal scales varied by area. The model for Nain charr had a significant year $\times$ month interaction term so we examined month-specific differences separately. We observed diet differences for captured fish among areas (Inshore and Offshore) and years in Nain for both July ( $\mathrm{p}<0.001$ for both area and year) and August ( $p=0.001$ for area; $p=0.03$ for year), whereas we only detected differences in the Northern stock across years $(p=0.002)$ and not months $(p=0.48)$. For Nain Inshore stocks, capelin tended to be abundant in charr stomachs in July (but also present in August). Decadal patterns were also evident (Fig. 3B), with samples from the 1980s grouping very differently from those in the early 1990s and an intermediate state observed in the 2000s. While not a planned statistical comparison, we assessed decadal groupings within a PERMANOVA framework for Nain Inshore and Nain Offshore areas. The full model that included decade and area as fixed effects had a significant interaction. When each area was run separately, pairwise comparisons showed that all decades were significantly different from one another in both areas but that the difference between the 1990s and 2000 s in the Nain Offshore area was weaker and only marginally significant $(\mathrm{p}=0.046$ compared to $\mathrm{p}<0.001$ for the others). Interestingly, this decadal pattern was shared across the Nain areas (Inshore and Offshore) as the correlation in interannual patterns was significant across the years when data was available for both locations ( $\mathrm{rho}=0.351, \mathrm{p}=0.004$ ) Capelin appeared to be a key driver of the observed temporal patterns in Nain, especially compared to other fish prey such as sand lance (Fig. 4). Effective population size of charr in Nain Inshore also showed interannual patterns with a mean decline of $34.3 \%$ (range $32.9-36.8 \%$ ) between the first (1990) and second (2001) time point that corresponds to declines in capelin in their diets (Fig. 4). All populations recovered by the third time point to a mean of $95.9 \%$ (range $83.0-109.6 \%$ ) of their original population size.

Charr sampled from Nain Offshore for diet analyses were generally larger in most years than those captured within the fjords of Nain (Fig. 5A). Moreover, mean sizes of fish sampled from Nain Offshore 
Fig. 4. (A) Average weight of prey items in diets of individual charr (solid lines; grey shaded areas represent $95 \%$ CIs of the GAM smoothing function) from Nain Inshore and Nain Offshore from 1986-2008 and (B) corresponding estimates of effective population size $\left(N_{\mathrm{e}}\right)$ (number of individuals) in rivers associated with Nain Bay from 1990-2013 that were derived from Layton et al. (2021). Error bars represent $95 \%$ confidence intervals
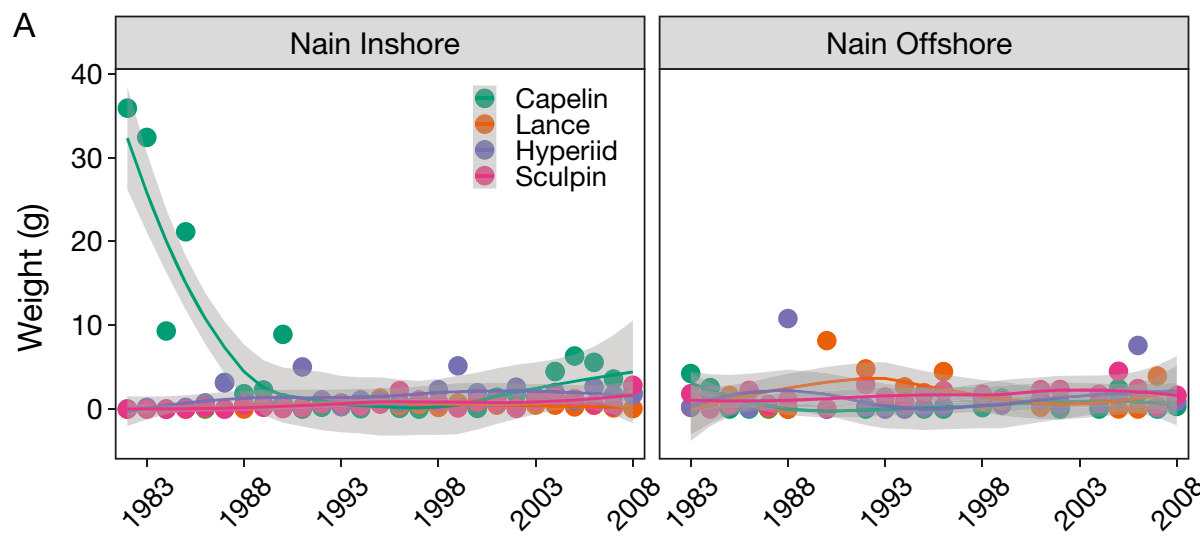

Year
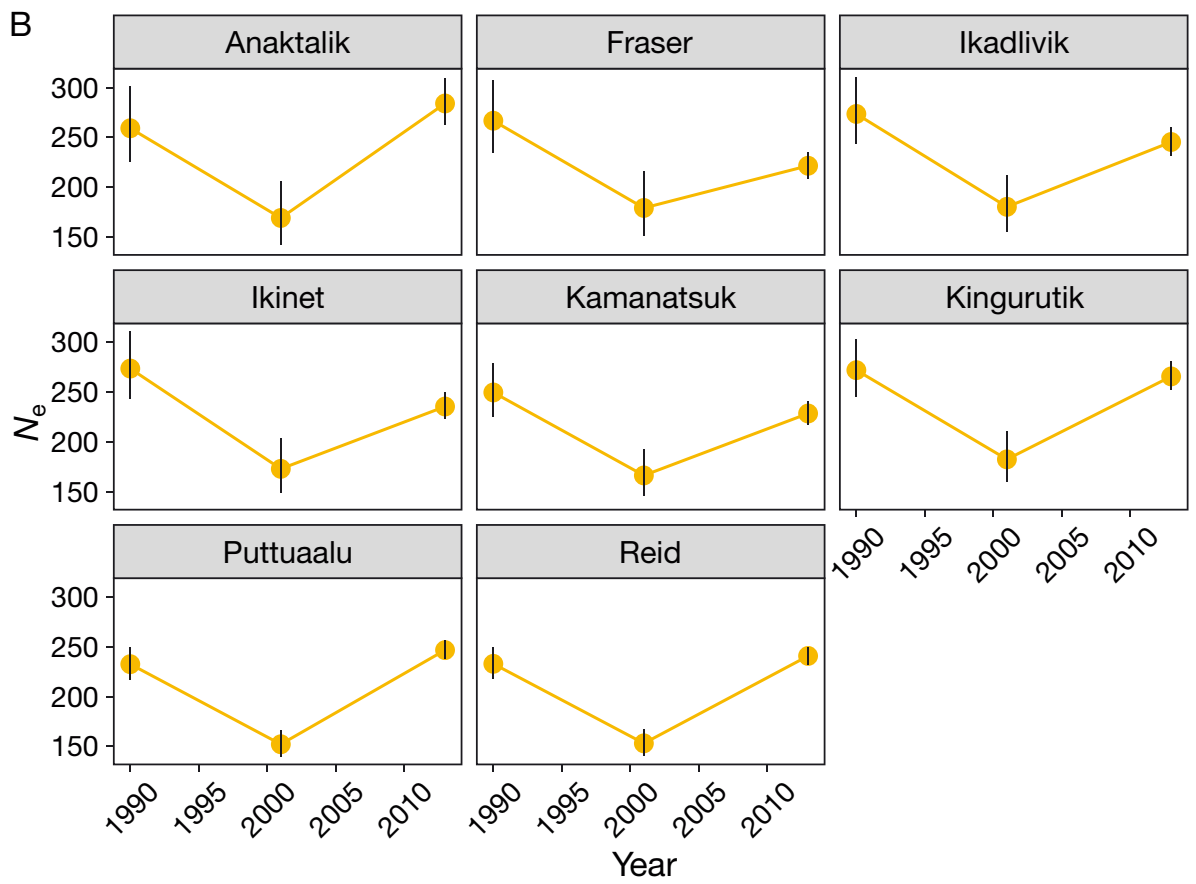

did not vary across years to the same degree as those captured from Nain Inshore (Fig. 5A). Stomach fullness data also revealed differences between the 2 areas over the time series (Fig. 5B). In Nain Offshore, stomach fullness was more consistent (typically averaging in the 50-60\% range), with notable exceptions in 1996 and 2001. In contrast, Nain Inshore stomach fullness was consistently lower than Offshore throughout the late 1980s and 1990s before exceeding Offshore values in the early 2000s and peaking in 2005. Across all years, there was a tendency for more charr to be captured in commercial fisheries offshore of Nain when stomach fullness of Nain Inshore charr was low $\left(F_{1,20}=12.51, p=0.002, R^{2}=0.385\right.$; Fig. $\left.5 C\right)$. Such a pattern was also found when using catch per unit effort (CPUE) as response variable $\left(F_{1,20}=6.60\right.$; $\mathrm{p}=0.018, \mathrm{R}^{2}=0.248$ ).

\section{DISCUSSION}

Arctic charr demonstrated the capacity to buffer the effects of broad environmental change through shifts in habitat use and diet. While behavioral plasticity is an important trait for dealing with a variable environment, it was insufficient to fully safeguard populations from the broad ecosystem changes experienced in the 1990s, even in areas that were under less harvesting pressure (Layton et al. 2021). It is likely, however, that behavioral plasticity has played a key role in the observed recovery in effective population size of charr in our study area and other parts of the Labrador Coast (Layton et al. 2021) despite only a partial recovery of capelin in their diets.

Charr are generalist feeders utilizing a variety of fish and invertebrate taxa (Klemetsen et al. 2003), 


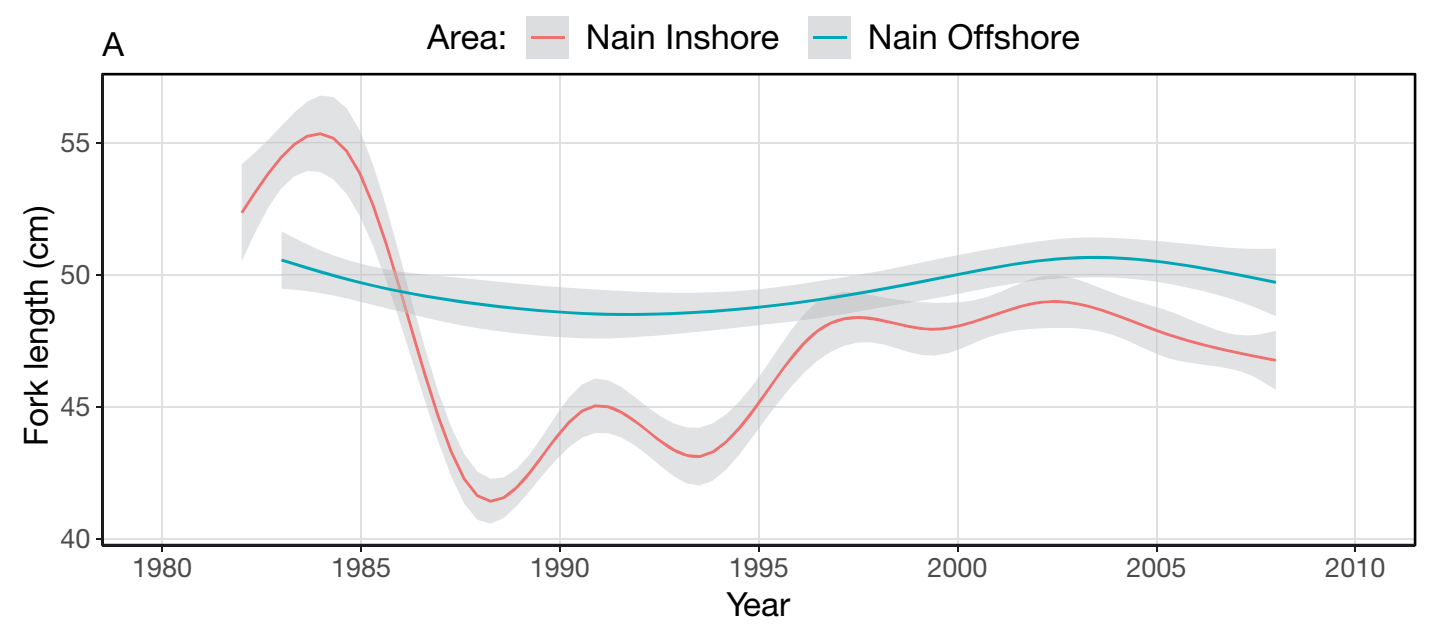

B
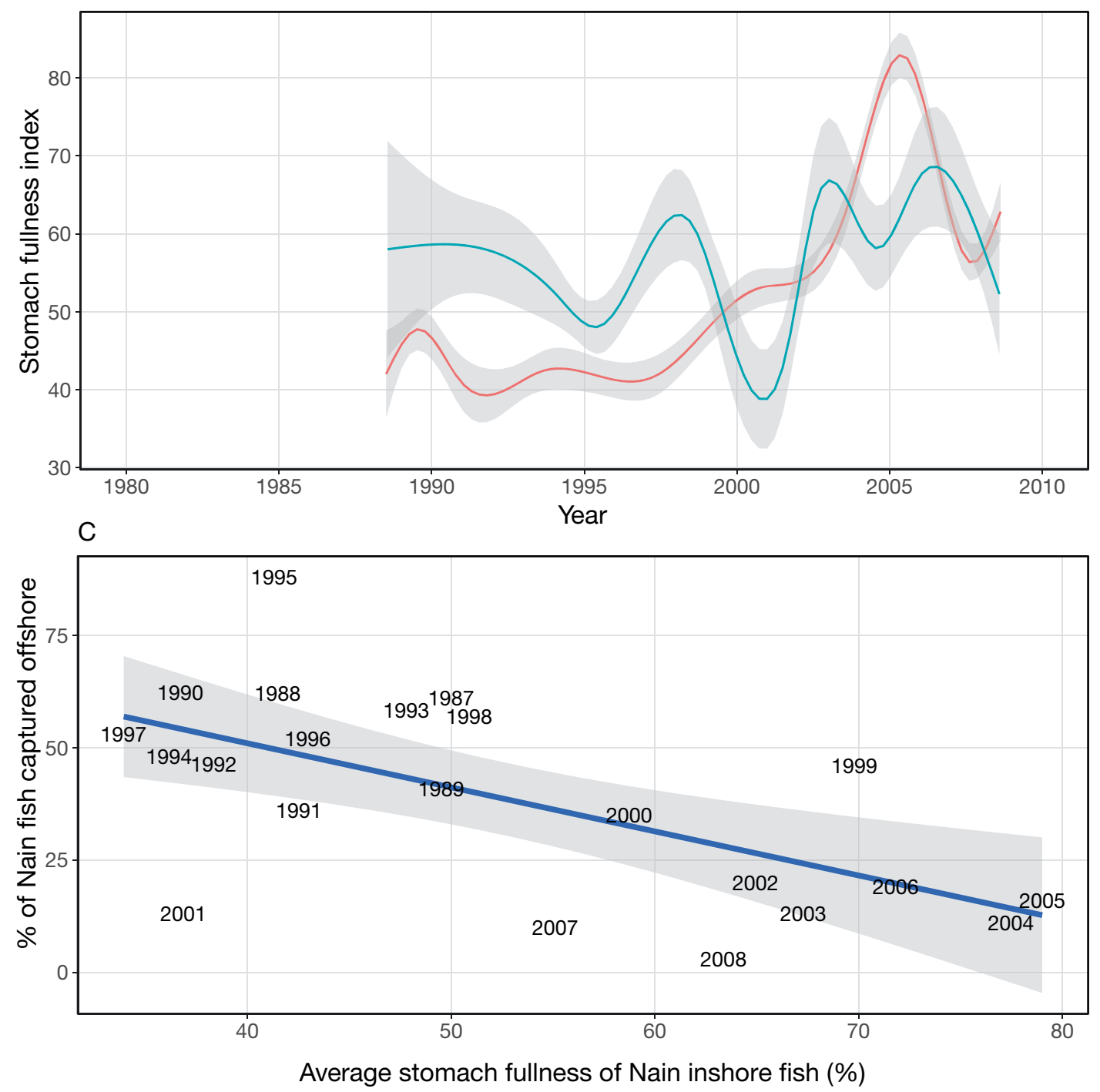

Fig. 5. Changes to average (A) fork length and (B) stomach fullness of Arctic charr sampled for diet analyses from Nain Inshore and Nain Offshore. (C) Catch of Arctic charr captured in Nain Offshore compared to stomach fullness of charr captured in Nain Inshore. Trend lines in (A) and (B) represent GAM cubic regression smoothers with $95 \%$ confidence intervals. Trend line in (C) indicates the linear model and shaded area represents $95 \%$ confidence intervals 
which enhances their capacity to endure fluctuating prey bases. In addition to varying across stocks, diet composition changed across months during the marine phase and also shifted over decadal scales, presumably in response to prey availability. In southern portions of our study area, where piscivory on capelin was most prominent (Dempson et al. $2002,2008)$, we observed year to year diet variation. Capelin abundance and distribution in the north Atlantic is dynamic (Carscadden et al. 2013) and low capelin abundance was a characteristic of the regime shift documented in the 1990s (Pedersen et al. 2017, Buren et al. 2019) that was captured in diet studies of Atlantic cod (Taggart et al. 1994), harp seals Phoca groenlandica (Lawson \& Stenson 1995), and murres Uvia spp. (Bryant et al. 1999). For example, capelin was 'virtually absent' in the diet of Atlantic cod on the coast of Labrador in 1991 and 1992 (Taggart et al. 1994). On the Gannet Islands of Labrador, feeding on capelin by murres dropped by up to $75 \%$ in the early 1990 s and shifted to daubed shannies Lumpenus maculatus (Bryant et al. 1999), whereas harp seals shifted to a diet dominated by Arctic cod in the late 1980s and early 1990s (Lawson \& Stenson 1995). The timing and nature of these diet shifts correspond to those observed in charr in Nain, which became more similar to those observed from Northern fjords (i.e. dominated by invertebrates and sculpins).

Associated with diet shifts away from capelin was a tendency for Nain charr to be captured at the coastal headlands in commercial fisheries. The combination of the absence of capelin and the low stomach fullness of charr remaining in inshore areas suggest that charr in Nain will adjust foraging behavior, leaving to search for capelin or other prey when it is not available closer to natal rivers. Tagged individuals in Nain also showed the capacity to change foraging habitats; altering their use of fjord and coastal habitats from one year to the next. Based on specimens obtained for diet analyses, charr caught in the Nain Offshore area were frequently larger than those from Nain Inshore areas. This pattern was noted previously where commercial fishery samples of charr from inshore bays were generally smaller beginning in the early 1990s by comparison with those caught offshore (Dempson 1995, Dempson et al. 2004). While part of this could have been associated with temporal differences either in the timing of migrations back to freshwater or timing of sampling (Dempson 1995), it is also likely that offshore areas provided enhanced feeding opportunities as evidenced from higher stomach fullness data.
In comparison to some other anadromous species (e.g. Atlantic and Pacific salmon), charr do not range far from natal rivers during the marine phase (Dempson \& Kristofferson 1987, Spares et al. 2015, Moore et al. 2016, Layton et al. 2021; in this study $<50 \mathrm{~km}$ ) and accordingly, are constrained to foraging on local prey assemblages. However, our results suggest that within this range, charr can adjust foraging habitats depending on local conditions. Other studies have documented plasticity in foraging over diel (Spares et al. 2012, Mulder et al. 2020) and seasonal timeframes (Harris et al. 2020) during the marine phase of charr. For example, Harris et al. (2020) observed that foraging patterns (i.e. diving behavior) shifted to deeper waters as the summer season progressed. Unlike this study, however, these authors did not observe foraging patterns to change across years, despite different environmental conditions. Certainly, there is an expectation that foraging plasticity of Arctic charr has limits when dealing with environmental change. A genomic study across several regions of northern Canada (including Labrador) showed region-specific adaptations to marine conditions, specifically to summer sea surface temperature, salinity, tides, turbidity, and air temperature (Dallaire et al. 2021). Furthermore, population level impacts have coincided with extreme environmental conditions (Layton et al. 2021), including the populations tracked in this study.

Charr migrate to marine habitats to increase growth (Gross et al. 1988). They do this by occupying physiologically advantageous habitats (temperature and salinity) and seeking out rich feeding areas. Estuaries appear to meet these conditions (Harris et al. 2020). However, the observation that charr undertake potentially costly migrations to coastal headlands when capelin are in low abundance indicates the importance of this prey species to Nain charr populations. Where available, capelin provide a comparably rich food source for charr (Lawson et al. 1998, Fall \& Fiksen 2020) and perhaps, in addition to earlier maturation and frequent spawning (Dempson 1995, Power et al. 2005), this explains why commercial harvests from the Nain stock complex were sustained at high levels (averaged 70.5 tonnes annually; 2116 tonnes total from 1977 to 1989) despite harvest rates averaging $42 \%$ of the exploitable stock (Dempson 1995).

Over time, diet studies of Nain charr reflect 3 ecosystem states, beginning with abundant capelin in the 1980s, followed by very low capelin abundance in the 1990s, and intermediate abundance in the early 2000s. Since that time, local knowledge holders have yet to observe capelin rebound to the levels observed 
in the 1980s (J. Angnatok pers. obs.). These trends are generally mirrored in capelin bycatch off northern Labrador (Carscadden et al. 2013). In contrast, capelin were more consistently at low biomass in charr stomachs from northern fjords (Saglek, Hebron, and Ramah) compared to Nain and Okak (Andrews \& Lear 1956, present study). Unfortunately, we have no contemporary surveys to establish the current state of the prey base on the Labrador Coast. Temperate species like capelin are expected to become increasingly common in the north as the climate warms (Reist et al. 2006, Carscadden et al. 2013, Tai et al. 2019), and could provide an expanded prey base for more northern fish populations. Indeed, researchers have already reported capelin in charr diets of Arctic populations in recent years (Spares et al. 2012, McNicholl et al. 2017, Harris et al. 2020).

Predicting responses of charr to climate change remains challenging. Northward expansion of key prey like capelin could provide an important food source for the low productivity coastal ecosystems found along the north coast of Labrador (Murdoch et al. 2015). Comparisons of Ungava and Labrador showed that slightly elevated temperatures coupled with higher local productivity were associated with notably better growth of Ungava charr (Murdoch et al. 2015). Conversely, the concomitant ecosystem changes that facilitate the northward expansion of prey may have negative effects on charr. For example, growth is dependent on interactions between water temperature, prey availability, and seasonal phenologies (Power et al. 2012, Murdoch et al. 2015). Charr growth is most efficient at lower temperatures when food is limited (Larsson \& Berglund 2005). Therefore, it is possible that increases in prey availability may not overcome the reduced growth efficiency associated with warmer water. Positive benefits to charr are further limited by the potential for increased competition from temperate salmonids (Power et al. 2012) and existing population adaptations that make it difficult for anadromous charr to thrive in warmer conditions (Layton et al. 2021). Such factors might drive populations with partial migration (i.e. exhibit both anadromous and resident life histories) to shift to resident life histories as the benefits of anadromy fade (Davidsen et al. 2020, Layton et al. 2021). In Nain, despite recovering effective population sizes of local populations and improving capelin abundance in charr diets, local harvesters have reported charr to be smaller and in lower abundance (Dempson et al. 2008, J. Angnatok pers. obs.); an indication that the fishery, although greatly reduced from earlier times, is becoming less sustain- able. Whether these trends are caused by more concentrated fishing effort near communities or deteriorating environmental conditions is not known.

Telemetry data provide insights that can be difficult to obtain using conventional mark-recapture techniques. For example, timing of migration to and from marine habitats (Dempson \& Green 1985, Dempson \& Kristofferson 1987, Bégout Anras et al. 1999, Gulseth \& Nilssen 2000, Jensen \& Rikardsen 2012, Moore et al. 2016), occupancy patterns of different marine habitats (Dempson \& Kristofferson 1987, Spares et al. 2015, Moore et al. 2016), and foraging behavior (inferred from diving data; Spares et al. 2012, Harris et al. 2020, Mulder et al. 2020) are more difficult to quantify with conventional techniques. Estuaries were a key marine habitat to charr in both study areas, with charr spending considerable time in these areas early in summer. Similar observations were found in Frobisher Bay (Spares et al. 2015) and Cambridge Bay (Moore et al. 2016, Harris et al. 2020) in Arctic regions of Canada. Estuaries are important habitats that provide favorable thermal environments and access to food resources (Spares et al. 2015), and possibly refuges from higher salinity waters (Harris et al. 2020). The mechanism driving heightened use of other marine habitats in Saglek remains unknown. It may be driven by differences in productivity between the 2 regions, but the productivity patterns of coastal habitats off Labrador remain poorly understood (McCarney et al. in press). An alternate explanation is that estuaries of both areas have comparable productivity but that Nain estuaries may be more attractive in years when they experience influx of migratory prey like capelin. Certainly, tagged charr in Nain illustrated that motivation to incorporate other non-estuarine habitats can vary from year to year.

There are few studies (but see Dempson \& Kristofferson 1987, Dempson et al. 2002, Spares et al. 2012) that link observations of marine behavior of charr to spatial and temporal variation in diet. Complementary data streams such as these (i.e. diet and commercial harvests) provide a more robust and holistic picture of charr behavior while in the ocean and illustrate the importance of long-term datasets. Even in this circumstance, where historical diet and commercial catch data did not temporally overlap with contemporary telemetry data, our confidence in the likelihood that marine behavioral differences observed across Saglek and Nain charr populations persist over time is bolstered by the consistency of diet differences among fjords over decadal scales. The complexity of dynamic prey fields and small-scale spatial 
variation in marine behavior, super-imposed upon a changing climate, is a challenge to predicting and managing responses of charr to commercial and food fisheries. Understanding how productivity cycles fluctuate in conjunction with changing environmental conditions will help to predict subsequent impacts on the marine behavior of local charr populations. While our study shows charr are capable of surviving regime shifts in part by altering habitat use, prey community shifts expected with climate change (Perry et al. 2005, Rose 2005b) will add to other climaterelated stressors that are expected to have widespread impacts on anadromous charr populations (Layton et al. 2021). With this in mind, recent concerns about the health of charr populations near Nain suggest renewed monitoring efforts of charr and the coastal ecosystem are needed to support sustainable management of this critical cultural (Berkes 2018) and commercial (Power \& Reist 2018) resource.

Acknowledgements. The extensive datasets used in this study were reliant on the dedication and innovation of many residents of Nunatsiavut (Food Skills and Environmental Research Program), technicians and biologists from DFO (J. Seiden, D. Lancaster, M. Shears, M. Bloom, S. Duffy), the Nunatsiavut Government (P. McCarney, C. Andersen, L. Pijogge), Oceans North (S. Pain), and the captains and crew of the 'What's Happening' and the 'Safe Passage'. Suggestions by 3 anonymous reviewers also greatly improved the manuscript. Funding for this research was provided in part by ArcticNet and DFO Oceans.

\section{LITERATURE CITED}

Anderson EC (2017) Rubias - genetic stock identification (GSI) in the tidyverse. https://github.com/eriqande/rubias

Anderson MJ (2001) A new method for non-parametric multivariate analysis of variance. Aust Ecol 26:32-46

Andrews CW, Lear E (1956) The biology of Arctic char (Salvelinus alpinus L.) in northern Labrador. J Fish Res Board Can 13:843-860

Bégout Anras ML, Gyselman EC, Jorgenson JK, Kristofferson AH, Auras L (1999) Habitat preferences and residence time for the freshwater to ocean transition stage of Arctic charr. J Mar Biol Assoc UK 79:153-160

Berkes F (2018) Arctic fish, northern cultures, and traditional ecological knowledge. In: Coad BW, Reist JD (eds) Marine fishes of Arctic Canada. Canadian Museum of Nature, Toronto, p 57-60

Bray JR, Curtis JT (1957) An ordination of the upland forest communities of southern Wisconsin. Ecol Monogr 27: 325-349

Brown T, Reimer K, Sheldon T, Bell T (2012) A first look at Nunatsiavut Kangidualuk ('fjord') ecosystems. In: Allard M, Lemay M (eds) Nunavik and Nunatsiavut: from science to policy. An Integrated Regional Impact Study (IRIS) of climate change and modernization. ArcticNet, Quebec City, p 271-301

Bryant R, Jones IL, Hipfner JM (1999) Responses to changes in prey availability by common murres and thickbilled murres at the Gannet Islands, Labrador. Can J Zool 77: 1278-1287

Bundy A, Heymans JJ, Morissette L, Savenkoff C (2009) Seals, cod and forage fish: a comparative exploration of variations in the theme of stock collapse and ecosystem change in four Northwest Atlantic ecosystems. Prog Oceanogr 81:188-206

Buren AD, Murphy HM, Adamack AT, Davoren GK and others (2019) The collapse and continued low productivity of a keystone forage fish species. Mar Ecol Prog Ser 616: 155-170

* Carscadden JE, Gjøsæeter H, Vilhjálmsson H (2013) A comparison of recent changes in distribution of capelin (Mallotus villosus) in the Barents Sea, around Iceland and in the Northwest Atlantic. Prog Oceanogr 114:64-83

Colbourne EB (2004) Decadal changes in the ocean climate in Newfoundland and Labrador waters from the 1950s to the 1990s. J Northwest Atl Fish Sci 34:43-61

Dallaire X, Normandeau É, Mainguy J, Tremblay JÉ, Bernatchez L, Moore JS (2021) Genomic data support management of anadromous Arctic Char fisheries in Nunavik by highlighting neutral and putatively adaptive genetic variation. Ecol Appl 14:1880-1897

* Davidsen JG, Power M, Knudsen R, Sjursen AD, Kjærstad G, Rønning L, Arnekleiv JV (2020) Marine trophic nicheuse and life history diversity among Arctic charr Salvelinus alpinus in southwestern Greenland. J Fish Biol 96: 681-692

Dempson JB (1995) Trends in population characteristics of an exploited anadromous Arctic charr, Salvelinus alpinus, stock in northern Labrador. Nord J Freshw Res 71: $197-216$

* Dempson JB, Green JM (1985) Life history of anadromous Arctic charr, Salvelinus alpinus, in the Fraser River, northern Labrador. Can J Zool 63:315-324

Dempson JB, Kristofferson AH (1987) Spatial and temporal aspects of the ocean migration of anadromous Arctic char. Am Fish Soc Symp 1:340-357

* Dempson JB, Shears M, Bloom M (2002) Spatial and temporal variability in the diet of anadromous Arctic charr, Salvelinus alpinus, in northern Labrador. Environ Biol Fishes 64:49-62

Dempson JB, Shears M, Furey G, Bloom M (2004) Review and status of north Labrador Arctic charr, Salvelinus alpinus. CSAS Res Doc 2004/070

* Dempson JB, Shears M, Furey G, Bloom M (2008) Resilience and stability of north Labrador Arctic charr, Salvelinus alpinus, subject to exploitation and environmental variability. Environ Biol Fishes 83:57-67

Fall J, Fiksen $\varnothing$ (2020) No room for dessert: a mechanistic model of prey selection in gut-limited predatory fish. Fish Fish 21:63-79

* Gower JC (1966) Some distance properties of latent root and vector methods used in multivariate analysis. Biometrika 53:325-338

Gross MR, Coleman RM, McDowall RM (1988) Aquatic productivity and the evolution of diadromous fish migration. Science 239:1291-1293

Gulseth OA, Nilssen KJ (2000) The brief period of spring migration, short marine residence, and high return rate of a northern Svalbard population of Arctic Char. Trans Am Fish Soc 129:782-796

* Harris LN, Yurkowski DJ, Gilbert MJH, Else BGT and others (2020) Depth and temperature preference of anadromous Arctic char Salvelinus alpinus in the Kitikmeot Sea, 
a shallow and low-salinity area of the Canadian Arctic. Mar Ecol Prog Ser 634:175-197

Hollenbeck CM, Portnoy DS, Gold JR (2016) A method for detecting recent changes in contemporary effective population size from linkage disequilibrium at linked and unlinked loci. Heredity 117:207-216

Jensen JLA, Rikardsen AH (2012) Archival tags reveal that Arctic charr Salvelinus alpinus and brown trout Salmo trutta can use estuarine and marine waters during winter. J Fish Biol 81:735-749

Johnson L (1980) The Arctic charr, Salvelinus alpinus. In: Balon EK (ed) Charrs, salmonid fishes of the genus Salvelinus. Dr. W. Junk Publishers, The Hague, p 15-98

Klemetsen A, Amundsen PA, Dempson JB, Jonsson B, Jonsson N, O'Connell MF, Mortensen E (2003) Atlantic salmon, Salmo salar L., brown trout, Salmo trutta L., and Arctic charr Salvelinus alpinus (L.): a review of aspects of their life histories. Ecol Freshwat Fish 12:1-59

Kacroix GL, Knox D, McCurdy P (2004) Effects of implanted dummy acoustic transmitters on juvenile Atlantic salmon. Trans Am Fish Soc 133:211-220

Larsson S, Berglund I (2005) The effect of temperature on the energetic growth efficiency of Arctic charr (Salvelinus alpinus L.) from four Swedish populations. J Therm Biol 30:29-36

Lawson JW, Stenson GB (1995) Historic variation in the diet of harp seals (Phoca groenlandica) in the northwest Atlantic. In: Blix AS, Walløe L, Ulltang $\varnothing$ (eds) Whales, Seals, Fish and Man: Proc Int Symp Biol Mar Mamm N East Atl, 29 November to 1 December, 1994, Dev Mar Biol, Elsevier Press, Amsterdam, p 261-269

*Lawson JW, Magalhäes AM, Miller EH (1998) Important prey species of marine vertebrate predators in the northwest Atlantic: proximate composition and energy density. Mar Ecol Prog Ser 164:13-20

Layton KKS, Dempson JB, Snelgrove PVR, Duffy SJ and others (2020) Resolving fine-scale population structure and fishery exploitation using sequenced microsatellites in a northern fish. Evol Appl 13:1055-1068

K Layton KKS, Snelgrove PVR, Dempson JB, Kess T and others (2021) Genomic evidence of past and future climate-linked loss in a migratory Arctic fish. Nat Clim Chang 11:158-165

McCarney P, Cote D, Laing R, Wells N and others (in press) Biophysical and ecological overview of a study area within the Labrador Inuit Settlement Area zone. DFO Can Sci Adv Sec Res Doc 2018

McNicholl DG, Wolki B, Ostertag S (2017) Traditional ecological knowledge and local observations of Capelin (Mallotus villosus) in Darnley Bay, NT. Can Manuscr Rep Fish Aquat Sci 3144

Mills KE, Pershing AJ, Sheehan TF, Mountain D (2013) Climate and ecosystem linkages explain widespread declines in North American Atlantic salmon populations. Glob Change Biol 19:3046-3061

*Montevecchi WA, Myers RA (1997) Centurial and decadal oceanographic influences on changes in northern gannet populations and diets in the north-west Atlantic: implications for climate change. ICES J Mar Sci 54: 608-614

* Moore JS, Harris LN, Kessel ST, Bernatchez L, Tallman RF, Fisk AT (2016) Preference for nearshore and estuarine habitats in anadromous Arctic char (Salvelinus alpinus) from the Canadian high Arctic (Victoria Island, Nunavut) revealed by acoustic telemetry. Can J Fish Aquat Sci 73: $1434-1445$
Moore JK, Fu W, Primeau F, Britten GL and others (2018) Sustained climate warming drives declining marine biological productivity. Science 359:1139-1143

* Moran BM, Anderson EC (2019) Bayesian inference from the conditional genetic stock identification model. Can J Fish Aquat Sci 76:551-560

* Mulder IM, Morris CJ, Dempson JB, Fleming IA, Power M (2020) Marine temperature and depth use by anadromous Arctic char correlates to body size and diel period. Can J Fish Aquat Sci 77:882-893

Murdoch A, Dempson JB, Martin F, Power M (2015) Temperature-growth patterns of individually tagged anadromous Arctic charr Salvelinus alpinus in Ungava and Labrador, Canada. Ecol Freshwat Fish 24:193-203

Nugent CM, Easton AA, Norman JD, Ferguson MM, Danzmann RG (2017) A SNP based linkage map of the Arctic charr (Salvelinus alpinus) genome provides insights into the diploidization process after whole genome duplication. G3 (Bethesda) 7:543-56

*Nugent CM, Leong JS, Christensen KA, Rondeau EB and others (2019) Design and characterization of an 87k SNP genotyping array for Arctic charr (Salvelinus alpinus). PLOS ONE 14:e0215008

Nutt DC (1953) Certain aspects of oceanography in the coastal waters of Labrador. J Fish Res Board Can 10: 177-186

* Pedersen EJ, Thompson PL, Ball RA, Fortin MJ and others (2017) Signatures of the collapse and incipient recovery of an overexploited marine ecosystem. R Soc Open Sci 4: 170215

*Perry AL, Low PJ, Ellis JR, Reynolds JD (2005) Climate change and distribution shifts in marine fishes. Science 308:1912-1915

Power M, Reist JD (2018) Salvelinus alpinus. In: Coad BW, Reist JD (eds) Marine fishes of Arctic Canada. Canadian Museum of Nature, Toronto, p 283-289

*Power M, Dempson JB, Power G, Reist JD (2000) Environmental influences on an exploited anadromous Arctic charr stock in Labrador. J Fish Biol 57:82-98

*Power M, Dempson JB, Reist JD, Schwartz CJ, Power G (2005) Latitudinal variation in fecundity among Arctic charr populations in eastern North America. J Fish Biol 67:255-273

Power M, Dempson JB, Doidge B, Michaud W and others (2012) Arctic charr in a changing climate: predicting possible impacts of climate change on a valued northern species In: Allard M, Lemay M (eds) Nunavik and Nunatsiavut: from science to policy. An Integrated Regional Impact Study (IRIS) of climate change and modernization. ArcticNet, Quebec City, p 199-221

* Core Team (2020) R: a language and environment for statistical computing. R Foundation for Statistical Computing, Vienna. www.r-project.org

Reist JD, Wrona FJ, Prowse TD, Power M, Dempson JB, King JR, Beamish RJ (2006) An overview of effects of climate change on selected Arctic freshwater and anadromous fishes. Ambio 35:381-387

Keist JD, Power M, Dempson JB (2013) Arctic charr (Salvelinus alpinus): a case study of the importance of understanding biodiversity and taxonomic issues in northern fishes. Biodiversity (Nepean) 14:45-56

Rikardsen $\mathrm{AH}$, Diserud $\mathrm{OH}$, Elliott JM, Dempson JB, Sturlaugsson J, Jensen AJ (2007a) The marine temperature and depth preferences of Arctic char and sea trout. Fish Oceanogr 16:436-447 
Rikardsen AH, Dempson JB, Amundsen PA, Bjørn PA, Finstad B, Jensen AJ (2007b) Temporal variability in marine feeding of sympatric Arctic charr and sea trout. J Fish Biol 70:837-852

Rose GA (2005a) Capelin (Mallotus villosus) distribution and climate: a sea 'canary' for marine ecosystem change. ICES J Mar Sci 62:1524-1530

Rose GA (2005b) On distributional responses of North Atlantic fish to climate change. ICES J Mar Sci 62:1360-1374

Rowe S, Jones IL, Chardine JW, Elliot RD, Veitch BG (2000) Recent changes in the winter diet of murres (Uria spp.) in coastal Newfoundland waters. Can J Zool 78:495-500

Simo-Matchim AG, Gosselin M, Poulin M, Ardyna M, Lessard S (2017) Summer and fall distribution of phytoplankton in relation to environmental variables in Labrador fjords, with special emphasis on Phaeocystis pouchetii. Mar Ecol Prog Ser 572:19-42

Editorial responsibility: Konstantinos Stergiou, Thessaloniki, Greece

Reviewed by: 3 anonymous referees
Spares AD, Stokesbury MJW, O'Dor RK, Dick TA (2012) Temperature, salinity and prey availability shape the marine migration of Arctic char, Salvelinus alpinus, in a macrotidal estuary. Mar Biol 159:1633-1646

Spares AD, Stokesbury MJW, Dadswell MJ, O'Dor RK, Dick TA (2015) Residency and movement patterns of Arctic charr Salvelinus alpinus relative to major estuaries. J Fish Biol 86:1754-1780

Taggart CT, Anderson J, Bishop C, Colbourne E and others (1994) Overview of cod stocks, biology, and environment in the northwest Atlantic region of Newfoundland, with emphasis on northern cod. ICES Mar Sci Symp 198:140-157

Tai TC, Steiner NS, Hoover C, Cheung WWL, Sumaila UR (2019) Evaluating present and future potential of arctic fisheries in Canada. Mar Policy 108:103637

*WWood S (2019) Package 'mgcv'. https://cran.r-project.org/ web/packages/mgcv/mgcv.pdf

Submitted: December 2, 2020

Accepted: May 28, 2021

Proofs received from author(s): August 24, 2021 